\title{
The Relationship between Organizational Culture and Innovative Work Behavior for Sports Services in Tourism Enterprises
}

Authors' contribution:

A) conception and design of the study

B) acquisition of data

C) analysis and interpretation of data

D) manuscript preparation

E) obtaining funding

\author{
Ersin Eskiler ${ }^{1 \text { A-E }}$, Summani Ekici ${ }^{2}$ B,D Fikret Soyer $^{1 \text { B-D }}$, \\ Ihsan Sari ${ }^{1 \text { C-E }}$ \\ ${ }^{1}$ Sakarya University, Turkey \\ ${ }^{2}$ Mugla University, Turkey
}

KEYWORDS

\begin{abstract}
The innovative behavior of individuals in the workplace is the foundation of any high-performance organization, and thus a study on the factors that motivate or enable individuals' innovative behavior is critical (Scott, \& Bruce, 1994). Therefore, the aim of this research was to find the relationship between organizational culture and innovative work behavior (IWB) in tourism enterprises that market sports services. Considering the fact that IWB is crucial for tourism enterprises, exploring the factors that influence IWB could be beneficial. Correlation analysis revealed that IWB was found to be significantly correlating with cooperativeness $(r=0.442$, $\mathrm{p}<0.05)$, innovativeness $(\mathrm{r}=0.510, \mathrm{p}<0.05)$, consistency $(\mathrm{r}=0.522, \mathrm{p}<0.05)$, and effectiveness $(\mathrm{r}=0.554, \mathrm{p}<0.05)$. Additionally, stepwise regression analysis, which was conducted to discover whether organizational culture predicts IWB, showed a significant model: $\mathrm{F}_{(2-131)}=33.775, \mathrm{p}<0.05$. The model explained $33 \%$ of the variance in IWB (Adjusted $\mathrm{R}^{2}=0.33$ ). In general, our findings suggest that there is a relationship between organizational culture and IWB and that organizational culture significantly predicts IWB. As IWB is crucial for the enhanced performance and success of any organization, organizational culture should be organized in order to encourage employees in terms of IWB.

innovativeness, organizational culture, sports, tourism enterprise
\end{abstract}

\section{Introduction}

These days, the happiness and welfare of people are definitely the underlying reasons of every effort in which fast developments and changes occur. The welfare of people depends on the extent to which limited sources meet the unlimited demands of people. The sharing of helpful sources and scientific studies that aim to contribute to people's welfare and happiness is an interdisciplinary effort. The science of business administration is the focal point of these studies (Can et al., 1995).

Increased tourism activities resulting from the recent developments and innovations in sports, one of the stakeholders of tourism, bring new trends to sports tourism. It is obvious that the necessity to follow the latest developments has emerged for any enterprise that aims to deliver tourism and sports services. It is also necessary to ensure a balance of supply and demand. New visions are required to meet people's needs in sports, which have increased for several reasons and will continue increasing in the future. 
Moreover, it is also important to reveal the components of innovative work behavior (IWB) and the factors that affect it. At this point, it is possible to put forward two concepts for management strategies of enterprises that market sports services. The first one is organizational culture, and the second is IWB. We are especially interested in determining whether there is a relationship between organizational culture and IWB. Considering the fact that IWB is crucial for tourism enterprises, exploring the factors that influence IWB could be beneficial.

\section{Organizational culture}

Barnard (1994) stated that an organization is a system of activities or power of two or more people which have been consciously coordinated and put forward that an organization emerges when there are people who can communicate and act together to achieve common aims. Schein (1980) defined an organization as the coordination of activities achieved by people with common aims, work sharing, hierarchy and responsibility under an authority. Similarly, Marc et al., (1958) put forward that it is a social construction which is formed by relations among its members.

Culture is one of the most important social environmental factors in an organization; therefore, it affects the life and development of an organization. Organizational culture is a paradigm that allows us to see the reality of a culture. This paradigm presents routine processes, categories, and good and bad solutions for an organization. It also informs individuals about how to behave in their organization. In other words, it is a paradigm of an organization which shows shared constructions, shared language, and some references that enable individuals to resolve many problems (Atay, 2001). Organizational culture is the system of the behaviors, values, beliefs, and habits that direct individuals' behaviors in an organization (Dincer, 1992). Culture enables individuals to see certain behaviors that should be modeled and teaches personnel how to behave. In other words, organizational culture is the values and beliefs that shape individuals' behaviors in an organization (Guclu, 2003).

All organizations have a culture that could be good or bad, weak or strong. However, it is obvious that an organization that can sustain its presence and overcome its rivals has a unique culture that is shared by all its members. Japanese corporations are the most appropriate example of this. The most important point here is the role of organizational leaders and founders in developing an organizational culture. Second, applications of human resources are crucial for sharing this culture (Guclu, 2003). Moreover, an effective organizational culture is one of the crucial elements which affect an organization's ability to be successful in the long run (Yang et al., 2004). Yang (2007) proposed that nurturing a collaborative culture in a work group highly influences the sharing of knowledge. It was also suggested that in today's era of knowledge, managers should play facilitator and mentor roles that encourage employees to share their knowledge (Yang, 2007).

Organizational culture has four dimensions (see Figure 1), which are:

1. Cooperative culture. This culture focuses on flexibility, cooperation, knowledge sharing, trust, and teamwork. This cooperative culture works in a friendly environment. Team members share knowledge in teamwork. Every member has a responsibility in their team and has an inner flexibility to accomplish their duties. Relationships in this culture are based on trust.

2.Innovativeness. This culture has the features of innovation, creativity, enterprisingness, adaptability, and dynamism. The environment supports creativity in this culture. Innovativeness could be defined as the ability to produce something original. It could also be described as a process which directs employees to produce new, useful, and comprehensible outcomes (Kao, 1989). Therefore, it should not be overlooked that this sub-dimension of organizational culture has features that could support and develop the IWB of individuals.

3. Consistency. This culture focuses on the system, rules, regulations, uniformity, and productivity. The culture is highly organized and consistent. An innovative structure of corporations requires consistently researching new opportunities and facilities in a systematic manner. A consistent system, 
which will ensure a better understanding of social, demographic, and technological changes, is required for innovativeness to become a basic skill in enterprises (Cavus, \& Akgemci, 2008).

4. Effectiveness. This culture focuses on competitiveness, target accomplishment, production, and performance. A company which has the features of an effective culture is primarily result-oriented and profit-oriented. Innovations acquired by creativity provide a strong economy for enterprises and ensure the opportunity to obtain advantages for success (Gumusluoglu, \& Ilsev, 2009). Therefore, an effective culture strengthens the creative skills of employees. The adaptation of corporations to some environmental changes, and even their ability to give direction to these environmental alterations, depends on effectively managing the work processes which support and embrace innovativeness and creativity.

In this respect, organizational culture is one of the most important determinants of IWB and enables corporations to obtain competitive advantages (Gumusluoglu, \& Ilsev, 2009; Naranjo-Valencia et al., 2011; SanzValle et al., 2011). In other words, dimensions of organizational culture with its structural feature have an important function in removing obstacles which prevent innovativeness and IWB from spreading in organizations.

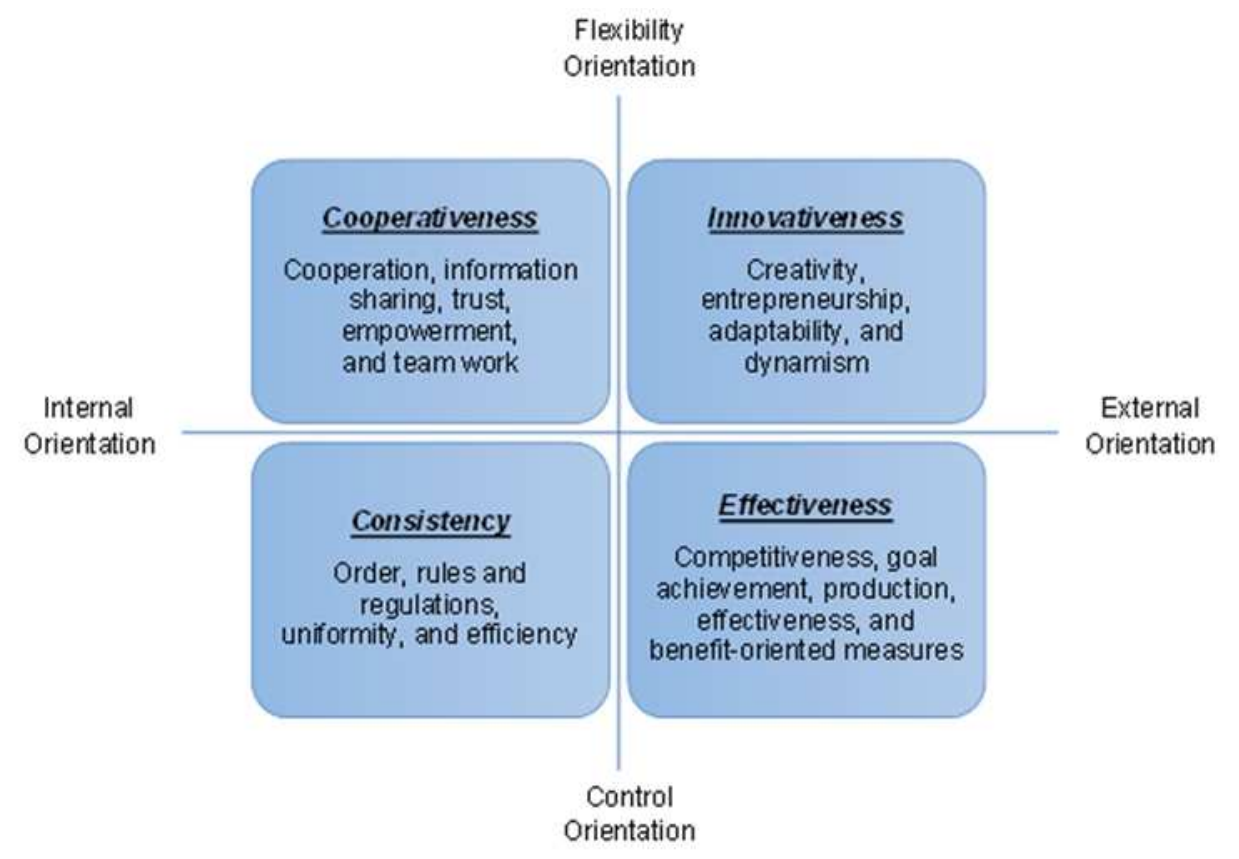

Figure 1. The model of organizational culture traits Source: Chang, \& Lin, 2007, p. 443.

\section{Innovative behavior}

Innovation has become the base of growth and competitiveness in the global economy (Petuskiene, \& Glinskiene, 2011). Groups in which innovative employees work are result- and profit-oriented. In the present age of rapid change, organizations have to engage in IWB in order to meet the demands which come from their environments. It is necessary to create and deliver the products and/ or services that they place on the market in order to be competitive and lead the process of change. Therefore, organizations need to use their employees to innovate their processes, methods, and operations in order to accomplish their aims (Ramamoorthy et al., 2005).

Farr and Ford (1990) define IWB as the behavior of individuals that aims to accomplish the initiation of new and useful ideas, processes, products, or procedures related to their work. IWB also refers to performing tasks beyond organizational routines that have been embraced by the members of an organization. The routines implemented by organizations may sometimes not be able to respond to a new situation quickly. Therefore, the development, endorsement, and implementation of new methods has become very important in today's dynamic business life (Shih, \& Susanto, 2011). As IWB is crucial for the performance of employees, many studies have been conducted in order to discover the factors which 
facilitate innovation (e.g., Mehra, \& Joshi, 2010; Luke et al., 2010; Scott, \& Bruce, 1994; Ramamoorthy et al., 2005; Jong, \& Hartog, 2007; Dorenbosch et al., 2005). Many studies have also been conducted in order to study innovation in detail (e.g., Parjanen et al., 2012; Zukauskaite, 2012; Gao, \& Zhang, 2011).

Lately, innovation research has focused on the factors that affect IWB. The factors that promote the development of innovation and initiate innovative activities are important for the promotion and adoption of innovation in organizations (Messmann, \& Mulder, 2011).

It was also pointed out that IWB is different from an employee's creativity, defined as the production of new and useful ideas about products, services, processes, and procedures (Amabile, 1988), as IWB includes the application of these new ideas. The aim of IWB is to obtain some kind of benefit that has an innovative result from innovative applications. Creativity can be categorized as an important component of IWB, and its importance clearly appears in the beginning of the innovation process where problems are detected and relevant solutions are generated as a result of the need for innovation (West, 2002; Jong, \& Hartog, 2010). Reuvers et al., (2008) stated that many researchers have claimed that encouraging employees leads to innovative behavior and is a crucial factor that positively affects performance and sustains the competitive advantage of an organization (e.g., Axtell et al., 2000; Dess et al., 2000; Drazin et al., 1996; Oldham et al., 1996). It was also stated that IWB is important for the organizational performance, success, and permanence of corporations (Gao, \& Zhang, 2011; Utterback, 1994; Balkin et al., 2000). For instance, in a recent study, Alpay et al., (2012) reported that dimensions of innovativeness have different effects on the marketing effectiveness and performance of firms.

Moreover, it was also pointed out that IWB is linked to the enjoyment that individuals get from their work, job satisfaction, increased performance in the workplace, better relationships with colleagues, lower stress, and satisfaction with personal development (West, \& Anderson, 1996; as cited in Shih, \& Susanto, 2011). Also, Walumbwa et al., (2009) reported that employees' willingness to learn could affect job performance.

Furthermore, it was stated that there is not much research investigating the effects of competencies on innovative behavior in organizations and examining this issue by looking at its relationship with higher education (Bjornali, \& Støren, 2012). Findings suggest that certain individual competencies and higher education programs which emphasize entrepreneurship and practice promote innovative behaviors. Professional, creative, communicative, championing, and brokering competencies were found to be particularly effective for IWB. It was also found that educational programs that emphasize the development of entrepreneurial skills and problem-based learning contribute to innovation (Bjornali, \& Støren, 2012).

In addition, most of the research on innovation has focused on the factors that enhance IWB (Chen, \& Aryee, 2007; Dorenbosch et al., 2005; Ramamoorthy et al., 2005; Scott, \& Bruce, 1994). However, there are also some studies which have examined its potential negative effects (Shih, \& Susanto, 2011; Janssen, 2003; Janssen et al., 2004). For instance, Shih and Susanto (2011) stated that IWB has a positive and significant relationship with conflict with co-workers and turnover intention. They argued that innovative employees engaging in IWB could face conflict with their co-workers. This is due to the fact that IWB destabilizes organizational routines, making other employees feel stressed and uncomfortable, leading to conflicts with co-workers.

In this study, it was initially thought that there could be a relationship between organizational culture and IWB, and that organizational culture could have an effect on IWB. When examining the relevant literature, some evidence was found to support this relationship. For instance, it was suggested that organization-based self-esteem and perceived fair interpersonal treatment are important for willingness to engage in IWB. The willingness to engage in IWB is the result of feelings of self-worth as a member of an organization and fair interpersonal treatment from others working in the same organization (Ojedokun, 2012). The innovative behaviors of individuals in the workplace constitute a strong basis for any high-performance organization, and thus it is critical to discover the factors that foster employees' innovative behavior (Scott et al., 1994; as cited in Carmeli et al., 2006). In addition, it was also stated that the process of innovation is enhanced for employees when they have, or feel that they have, opportunities in the workplace. 
The context of a job contains many components, such as other colleagues, supervisors, clients, work tasks, related rules and regulations, organizational routines, and all of the resources of the job. Therefore, the opportunities that could affect innovativeness range from a single workplace to an entire organization. If a work context is characterized by a positive climate that encourage high expectations and the development of new ideas, the IWB of employees is enhanced (Messmann, \& Mulder, 2011).

It has been shown that the visionary leadership behaviors of managers can effectively improve the perceived innovative interactions of neurotic employees in the workplace. However, if managers do not demonstrate visionary leadership behaviors, neurotic employees will perceive a reduction in their innovative interactions and an increase in their anxiety (Chen, \& Chen, 2013).

Therefore, it can be stated that there is a relationship between organizational climate/ organizational culture and IWB. Moreover, tourism is one of the most important industries in the world, and it has a major effect on the economies of most countries (Fayed, \& Fletcher, 2002). Employees in tourism organizations are the sources of innovation (Chen et al., 2010). Accordingly, the discovery of tourism employees' IWB, as well as its relationship with the employees' organizational culture, appears to be an important topic for the efficiency of organizational processes, the success of corporations, and consumers' satisfaction with the products in this sector. Thus, the aim of this study was to determine the relationship between organizational culture and IWB in tourism corporations that market sports services.

\section{Method}

\section{Participants and data collection}

The current study consisted of 134 managers from hotels located on the Mediterranean Sea coastline in 2012. The convenient sampling method was used in selecting the participants.

\begin{tabular}{|c|c|c|}
\hline & $\mathbf{n}$ & $\%$ \\
\hline \multicolumn{3}{|l|}{ Age } \\
\hline$<20$ & 4 & 3 \\
\hline $21-25$ & 26 & 19.4 \\
\hline $26-30$ & 47 & 35.1 \\
\hline $31-35$ & 20 & 14.9 \\
\hline $36-40$ & 17 & 12.7 \\
\hline $41<$ & 20 & 14.9 \\
\hline \multicolumn{3}{|l|}{ Gender } \\
\hline Male & 90 & 68.2 \\
\hline Female & 42 & 31.8 \\
\hline \multicolumn{3}{|l|}{ Length of work (years) } \\
\hline $1-5$ & 73 & 54.5 \\
\hline $6-10$ & 48 & 35.8 \\
\hline $11<$ & 13 & 9.7 \\
\hline \multicolumn{3}{|l|}{ Income Level } \\
\hline $0-1000 \mathrm{TL}$ & 21 & 15.8 \\
\hline $1001-1500 \mathrm{TL}$ & 55 & 41.4 \\
\hline $1501-2000 \mathrm{TL}$ & 45 & 33.8 \\
\hline $2001-2500 \mathrm{TL}$ & 12 & 9 \\
\hline \multicolumn{3}{|l|}{ Educational Status } \\
\hline Primary school & 16 & 12.3 \\
\hline High school & 65 & 50 \\
\hline Undergraduate & 49 & 37.7 \\
\hline \multicolumn{3}{|l|}{ Work Department } \\
\hline Entrance, reservation, reception & 24 & 17.9 \\
\hline Service, restaurant, bar, laundry & 52 & 38.8 \\
\hline Sports entertainment & 41 & 30.6 \\
\hline Front office & 17 & 12.7 \\
\hline
\end{tabular}

Source: own study. 
The socio-demographic characteristics of the participants can be seen in Table 1. Participants were contacted in their workplaces and informed about the questionnaires and the study. After informing the participants about the study, managers who agreed to join the study filled out the questionnaires. The data obtained using the questionnaire method were collected by experienced pollsters. Data was collected in the workplaces of the participants; this took approximately 10 minutes. The data collection was conducted between July and September during a three-month period. Participants were chosen from hotels that marketed sports services in a manner relevant to the aim of the current study. The participants were informed that participation was voluntary and that the data obtained from them would only be used for research purposes. The survey achieved a response rate of $67 \%$.

\section{Data collection tools}

Chang and Lin (2007) developed a questionnaire for measuring organizational culture; Uzkurt and Sen (2012) adapted this scale for the Turkish population. The questionnaire consists of 26 questions that were answered on the 5-point Likert scale. There are 4 subscales in total: cooperativeness (8 questions), innovativeness (6 questions), consistency (6 questions), and effectiveness (6 questions). In the present study, Cronbach's Alpha values of the subscales were $0.60,0.82,0.82$, and 0.84 , respectively.

A scale which was developed by Janssen (2001) was used to measure IWB. The scale consists of 9 questions which were answered on the 5-point Likert scale. Cronbach's Alpha for this scale was 0.85 in the current study. Apart from these scales, there were also 6 questions for measuring demographic characteristics.

\section{Data analysis}

First, all questionnaire data were combined into an SPSS file in the same order in which they appeared in the questionnaire. As a second step, data screening was conducted by inspecting the distributions of each variable and controlling for data entry errors by noting whether responses were in the range represented by the response format. The SPSS 17 Package Program was used to analyze the data. Descriptive statistics, Pearson's correlation analysis, and regression analysis were used to analyze the data. The stepwise regression analysis technique was used as a regression test in order to discover whether sub-dimensions of organizational culture predict IWB. The level of significance was determined to be 0.05 .

\section{Results}

Inspection of the descriptive statistics of organizational culture and IWB showed that effectiveness has the maximum score (4.3) among the sub-dimensions of organizational culture. Effectiveness is followed by innovation, with a mean value of 4.23. Cooperativeness and consistency have the same score of 4.22. The mean score of IWB was 4.32 (Table 2).

Table 2. Descriptive statistics of organizational culture and IWB

\begin{tabular}{llll}
\hline & Range & Mean & SD \\
\hline Cooperativeness & $1-5$ & 4.22 & .60 \\
Innovativeness & $1-5$ & 4.23 & .56 \\
Consistency & $1-5$ & 4.22 & .53 \\
Effectiveness & $1-5$ & 4.30 & .54 \\
IWB & $1-5$ & 4.32 & .44 \\
\hline
\end{tabular}

Source: own study.

Correlation analysis revealed that IWB was found to be positively and significantly correlating with cooperativeness $(r=0.442, p<0.05)$, innovativeness $(r=0.510, p<0.05)$, consistency $(r=0.522, p<0.05)$, and effectiveness $(\mathrm{r}=0.554, \mathrm{p}<0.05)$ (Table 3$)$. 
Table 3. Correlation of organizational culture and IWB

\begin{tabular}{|c|c|c|c|c|c|}
\hline & & 1 & 2 & 3 & 4 \\
\hline Cooperativeness & $\begin{array}{l}\mathbf{r} \\
\mathbf{p}\end{array}$ & 1 & & & \\
\hline Innovativeness & $\begin{array}{l}\mathbf{r} \\
\mathbf{p}\end{array}$ & $\begin{array}{l}.609 * * \\
.000\end{array}$ & 1 & & \\
\hline Consistency & $\begin{array}{l}\mathbf{r} \\
\mathbf{p}\end{array}$ & $\begin{array}{l}.513^{* *} \\
.000\end{array}$ & $\begin{array}{l}.718 * * \\
.000\end{array}$ & 1 & \\
\hline Effectiveness & $\begin{array}{l}\mathbf{r} \\
\mathbf{p}\end{array}$ & $\begin{array}{l}.588 * * \\
.000\end{array}$ & $\begin{array}{l}.677 * * \\
.000\end{array}$ & $\begin{array}{l}.714^{* *} \\
.000\end{array}$ & 1 \\
\hline IWB & $\begin{array}{l}\mathbf{r} \\
\mathbf{p}\end{array}$ & $\begin{array}{l}.442 * * \\
.000\end{array}$ & $\begin{array}{l}.510 * * \\
.000\end{array}$ & $\begin{array}{l}.522 * * \\
.000\end{array}$ & $\begin{array}{l}.554 * * \\
.000 \\
\end{array}$ \\
\hline
\end{tabular}

Source: own study.

Stepwise regression analysis showed a significant model: $\mathrm{F}_{(2-131)}=33.775, \mathrm{p}<0.05$. The model explains $33 \%$ of the variance in IWB (Adjusted $\mathrm{R}^{2}=0.33$ ). The results showed that effectiveness and innovativeness were the significant predictors of IWB.

\section{Discussion}

Recent studies and culture researchers have put forward new ideas on the topic of organizational culture (Guclu, 2003). The current state of the topic indicates that decision-making and its applications, as well as creating and organizing management types, refers to cultural changes. Organizations which are in the process of change and development need to change their culture. This case is most often a problem for managers in the tourism sector. The education system, management type and philosophy, social constructs, attitudes, predictions, and expectations of employees are affected in the process of change. The principles, values, and main ideas in the organization also start to change. Therefore, management science should develop IWB as the result of the nature of science. Creating a new organizational culture in tourism corporations does not mean creating a new motto or having a new manager; it refers to having a new lifestyle in line with changes and developments. Tourism and sports tourism are the sectors in which the necessity of having IWB appears in line with the above-mentioned developments.

According to the results of this research, which aimed to determine the relationship between organizational culture and IWB in tourism corporations that market sports services, IWB was found to be significantly correlating with cooperativeness $(r=0.442, p<0.05)$. These results show that cooperativeness in an organization correlates with IWB. It could be said that cooperation, harmony and the ability for members to work together are correlated with IWB. Furthermore, these results also show that efforts to encourage harmony and cooperation among group members are necessary for tourism corporations. The organizational culture of an enterprise should be more flexibility-oriented and internally-oriented in order to ensure cooperativeness, which supports IWB (Chang, \& Lin, 2007). Furthermore, the need for belonging and love, suggested by Maslow (1970), affection, suggested by Murray's Theory of Psychogenic Needs (Murray, 1938), and relatedness, put forward by Self-Determination Theory (Deci et al., 1996; Deci, \& Ryan, 2000) highlight the importance of human beings' need for belonging. Those who study these theories explain the importance of the need for belonging. The research on this topic shows that this basic need (the need for relatedness/ need for belonging) is significantly related to well-being, communication skills, self-efficacy, and anxiety (Sar1 et al., 2012). Harmony and cooperation among group members are important for the satisfaction of the need for belonging. Thus, it could be said that a highly cooperative culture in an enterprise could fulfil this need. The relationship between cooperativeness and IWB could be a result of the mediating effect of satisfying the need for belonging.

In addition, IWB was found to be positively and significantly correlating with innovativeness. Namely, having an innovative organizational culture has a linear relationship with IWB. This suggests that organizational culture in tourism corporations should support innovativeness for increasing employees' IWB. 
Managers working in the tourism sector, an indispensable part of modern life, should have a post-modern mentality, which can lead tourism organizations to success. People's need for sports tourism varies and intensifies every day. Sports tourism, which is a tool that people use to fulfil their need for self-actualization, renews itself every day in line with technological developments. In order to be parallel to these developments and changes, organizational culture should be open to innovations.

Moreover, IWB was found to be positively and significantly correlating with consistency. A consistent culture focuses on the system, rules, regulations, uniformity, and productivity. This culture type is highly organized and consistent. This sub-dimension of organizational culture emphasizes consistency in an organization. Consistency in an organization brings along stability and IWB. Therefore, the stability of general management policies ensures the stability of organizational culture, which in turn ensures the continuity of IWB.

According to another result, IWB was found to be positively and significantly correlating with effectiveness. This culture focuses on competitiveness, target accomplishment, production, and performance; in addition, this type of group is result- and profit-oriented. Managers can detect the opportunities and the risks in the market by finding the opportunity to closely follow the market and competing corporations by means of an effective organizational culture. Enterprises should be able to optimally respond to these opportunities and risks in an innovative manner in order to sustain their existence. Therefore, organizational culture is crucial for commercializing IWB outputs.

Furthermore, effectiveness and innovativeness, which are the sub-dimensions of organizational culture, significantly contributed to IWB in our regression model. There is not a consensus among previous researchers on which dimension of organizational culture is more effective for a more innovative enterprise (Uzkurt, \& Sen, 2012; Chang, \& Lin, 2007). It was found in this study that an externally-orientated structure of organizational culture could be more effective in supporting innovations in tourism enterprises which market sports services. It could be said that these differences which have been obtained by the researchers could stem from cultural features and individual and sectoral differences. In general, our findings suggest that organizational culture has a significant effect on IWB. When considering the fact that IWB is an important aspect of organization, organizational culture should be organized in order to encourage employees to engage in IWB. The importance of IWB has also been emphasized in previous research. For instance, findings from healthcare organizations have suggested that if healthcare professionals are to be encouraged to engage in IWB, it is beneficial to promote their flexible role orientation (Kessel et al., 2012). It has also been proven that innovation is the central mechanism by which organizations develop capabilities and adapt to their environments (Chin et al., 2011). It was also stated in a previous study that companies with stronger leadership, support from management, and motivational practices for their members are more innovative than their competitors (Zieba, \& Zieba, 2014).

In another study in education, it is suggested that some characteristics of teachers, such as job satisfaction, self-actualization, motivation, or openness, are among the factors which are closely related to teachers' perceptions of their work context. Teachers stated that they needed to adopt innovative behaviors because they faced problems or challenges in their work. They also needed to develop in their job, a process for which innovation is necessary. Although contextual factors and necessities for a job affect opportunities for innovative behaviors and motivation, the goals and the personality of teachers are also important for initiating IWB (Messmann, \& Mulder, 2011).

Relevant studies support our results. The results of a previous study suggest that innovation is a broad process of learning that enables the implementation of new ideas, products, or processes. Another characteristic of innovation is the assimilation of new ideas. Therefore, a positive learning climate is beneficial for firms that aspire to stand out through product development. It is important to point out that managers should encourage employees to effectively use their time to obtain necessary knowledge that may be found outside the scope of their work. Cross-functional integration enables employees to learn and develop their new skills and to share existing knowledge with their colleagues, which leads to the 
development of products, and thus to success (Xin et al., 2007). It has also been stated that being a learning organization is important. Modern society and modern organizations focus on ongoing change, and leading companies encourage their members to be innovative (Svagzdiene et al., 2013). For effective innovation, well-established norms, practices, and beliefs may have to be challenged. It is understandable that new product development requires continuous organizational renewal. Calantone et al., (2002) also pointed out that this competitive advantage is built on a full understanding of customer needs, competitors' actions, and technological development, an understanding made possible by an organizational commitment to learning. Firms without these attributes are less likely to stand out in terms of innovation capability, although they may look elsewhere to find ways to survive.

Moreover, Cavus and Akgemci (2008) suggested that organizations should be innovative in order to sustain their existence. In addition, results from another study indicate that if employees believe that they can influence their work environment, they are more likely to adopt innovative behaviors. In addition, in order to be innovative, employees should perceive that their supervisors are likely to support their innovative behaviors. This result indicates that the behaviors of supervisors are important for the IWB of employees (Janssen, 2005). Therefore, all of the environmental factors in a work context that could affect employees should be organized in a way that fosters IWB.

There are some limitations of this research. First, the results show the characteristic features of Turkish culture and the obtained results might vary depending on culture. Second, the findings of this research were obtained from a pen-and-paper survey. Thus, experimental design can be used in future research. Lastly, these findings represent the characteristics of tourism enterprises; future research could focus on other sectors to examine their differences.

\section{Conclusion}

The results of this research show that organizational culture could affect IWB. Relevant studies have suggested that organizational culture has an effect on innovativeness in an organization, which is parallel to our results. However, our research was conducted in the tourism sector and has a sports component. Therefore, we believe that the contribution of this research to the relevant literature is unique. The business life of the twenty-first century entails innovativeness. The results of our study show that organizational culture is an important factor for IWB in tourism corporations. Tourism corporations should introduce innovative applications to the market instead of imitating changes.

\section{REFERENCES}

Advi Alpay, G., Bodur, M., Yilmaz, C., \& Buyukbalci, P. (2012). How does innovativeness yield superior firm performance? The role of marketing effectiveness. Innovation: Management, Policy \& Practice, 14(1), 107-128. DOI:10.5172/impp.2012.14.1.107.

Amabile, T.M. (1988). A model of creativity and innovation in organizations. Research in Organizational Behaviour, 10, 123-167.

Atay, K. (2001). Okul kulturu /The culture of school/. Kuramdan Uygulamaya Egitim Yonetimi /Educational administration: Theory and Practicel, 23, 179-191.

Axtell, C.M., Holman, D.J., Unsworth, K., Wall, T.D., Waterson, P., \& Harrington, E. (2000). Shop-floor innovation: Facilitating the suggestion and implementation of ideas. Journal of Occupational Organizational Psychology, 73(3), 265-285. DOI: 10.1348/096317900167029.

Balkin, D.B., Markman, G.D., \& Gomez-Mejia, L.R. (2000). Is CEO pay in high-technology firms related to innovation? Academy of Management Journal, 43(6), 1118-1129. DOI: 10.2307/1556340.

Barnard, C. (1994). The functions of the executive. Cambridge: Harvard University Press. 
Bjornali, E.S., \& Storen, L.A. (2012). Examining competence factors that encourage innovative behaviour by European higher education graduate professionals. Journal of Small Business and Enterprise Development, 19(3), 402-423. DOI: $10.1108 / 14626001211250135$.

Calantone, R.J., Cavusgil, S.T., \& Zhao, Y. (2002). Learning orientation, firm innovation capability, and firm performance. Industrial Marketing Management, 31(6), 515-524. DOI: 10.1016/S0019-8501(01)00203-6.

Can, Y., Soyer, F., \& Can, S. (1995). Genel İsletmecilik Bilgisi ve Spor İsletmeciligine Giris /General Administrative Science and Administrative of Sport/. Kayseri: Ders Notları/Publication of Erciyes University/

Carmeli, A., Meitar, R., \& Weisberg, J. (2006). Self-leadership skills and innovative behavior at work. International Journal of Manpower, 27(1), 75-90. DOI: 10.1108/01437720610652853.

Cavus, M.F., \& Akgemci, T. (2008). İsletmelerde personel guclendirmenin orgutsel yaratıcılık ve yenilikcilige etkisi: İmalat sanayiinde bir arastırma /The effect of employee empowerment on organizational creativity and innovativeness: A research in the manufacturing industry/. Selcuk Universitesi Sosyal Bilimler Enstitüsü Dergisi /Selcuk University the Journal of Institute of Social Sciencel, 20, 229-244.

Chang, S.E., \& Lin, C.S. (2007). Exploring organizational culture for information security management. Industrial Management \& Data Systems, 107(3), 438-458. DOI: 10.1108/02635570710734316.

Chen, J.K., \& Chen, I.S. (2013). Don't worry, I'm with you: Can visionary leadership release neurotic employees for more perceived innovative interactions? Innovation: Management, Policy \& Practice, 15(2), $215-223$. DOI:10.5172/impp.2013.15.2.215.

Chen, S.C., Wu, M.C., \& Chen, C.H. (2010). Employee's personality traits, work motivation and innovative behaviour in marine tourism industry. Journal of Service Science \& Management, 3(2), 198-205. DOI: 10.4236/jssm.2010.32024.

Chen, Z.X., \& Aryee, S. (2007). Delegation and employee work outcomes: An examination of the cultural context of mediating processes in China. Academy of Management Journal, 50(1), 226-238. DOI: 10.2307/20159849.

Chin, W.H., Huang, L.C., \& Yang, T.J. (2011). Organizational culture and performance: The mediating roles of innovation capacity. African Journal of Business Management, 5(21), 8500-8510. DOI:10.12988/ces.2014.4219.

Deci, E.L., \& Ryan, R.M. (2000). The "what" and "why” of goal pursuits: Human needs and the self-determination of behavior. Psychological Inquiry, 11(4), 227-268. DOI:10.1207/S15327965PLI1104_01.

Deci, E.L., Ryan, R.M., \& Williams, G.C. (1996). Need satisfaction and the self-regulation of learning. Learning and Individual Differences, 8(3), 165-183. DOI: 10.1016/S1041-6080(96)90013-8.

Dess, G.G., \& Pickens, J.C. (2000). Changing roles: Leadership in the $21^{\text {st }}$ century. Organizational Dynamics, 28(3), 18-34. DOI: 10.1016/S0090-2616(00)88447-8.

Dincer, O. (1992). Stratejik Yonetim ve Isletme Politikasi /Strategic Management and Business Policy/. Istanbul: Alfa Publications.

Dorenbosch, L., Van Engen, M.L., \& Verhagen, M. (2005). On-the-job innovation: The impact of job design and human resource management through production ownership. Creativity \& Innovation Management, 14(2), $129-141$. DOI: 10.1111/j.1476-8691.2005.00333.x.

Drazin, R., \& Schoonhoven, C.B. (1996). Community, population, and organizational effects on innovation: A multilevel perspective. Academy of Management Journal, 39(5), 1065-1083.

Farr, J., \& Ford, C. (1990). Individual innovation. In M. West, \& J. Farr (Eds.), Innovation and creativity at work: Psychological and Organizational Strategies, (pp. 63-80). Chichester: Wiley.

Fayed, H., \& Fletcher, J. (2002). Globalization of economic activity: Issues for tourism. Tourism Economics, 8(2), $207-$ 230. DOI: $10.5367 / 000000002101298070$.

Gao, Q., \& Zhang, C. (2011). Analysis of innovation capability of 125 agricultural high-tech enterprises in China. Innovation: Management, Policy \& Practice, 13(3), 278-290. DOI:10.5172/impp.2011.13.3.278.

Guclu, N. (2003). Orgut kulturu /Organizational Culture/. Kırgızistan Manas Universitesi Sosyal Bilimler Dergisi /Kırgızistan Manas University the Journal of Institute of Social Sciencel, 6, 147-159.

Gumusluoglu, L., \& Ilsev, A. (2009). Transformational leadership, creativity, and organizational innovation. Journal of Business Research, 62(4), 461-473. DOI: 10.1016/j.jbusres.2007.07.032. 
Janssen, O. (2001). Fairness perceptions as a moderator in the curvilinear relationships between job demands, and job performance and job satisfaction. Academy of Management Journal, 44(5), 1039-1050. DOI: 10.2307/3069447.

Janssen, O. (2003). Innovative behaviour and job involvement at the price of conflict and less satisfactory relations with co-workers. Journal of Occupational and Organizational Psychology, 76(3), 347-364. DOI: $10.1348 / 096317903769647210$.

Janssen, O. (2005). The joint impact of perceived influence and supervisor supportiveness on employee innovative behaviour. Journal of Occupational and Organizational Psychology, 78(4), 573-580. DOI: 10.1348/096317905X25823.

Janssen, O., Van De Vliert, E., \& West, M. (2004). The bright and dark sides of individual and group innovation: A special issue introduction. Jurnal of Organizational Behaviour, 25(2), 129-145. DOI: 10.1002/job.242.

Jong, J.P.J., \& Hartog, D.N.D. (2007). How leaders influence employees' innovative behaviour. European Journal of Innovation Management, 10(1), 41-64. DOI: 10.1108/14601060710720546.

Jong, J.P.J., \& Hartog, D.N.D. (2010). Measuring innovative work behaviour. Creativity and Innovation Management, 19(1), 23-36. DOI: 10.1111/j.1467-8691.2010.00547.x.

Kao, J. (1989). Entrepreneurship, creativity and organization. UK: Prentice Hall.

Kessel, M., Weber, H.H., \& Kratzer, J. (2012). Innovative work behavior in healthcare: The benefit of operational guidelines in the treatment of rare diseases. Health Policy, 105(2-3), 146-153. DOI: 10.1016/j.healthpol.2012.02.010.

Luke, B., Verreynne, M., \& Kearins, K. (2010). Innovative and entrepreneurial activity in the public sector: The changing face of public sector institutions. Innovation: Management, Policy \& Practice, 12(2), 138-153. DOI: $10.5172 /$ impp.12.2.138.

March, J.G., \& Simon, H.A. (1958). Organizations. New York: John Wiley.

Maslow, A.H. (1970). Motivation and personality. New York: Harper.

Mehra, K., \& Joshi, K. (2010). The enabling role of the public sector in innovation: A case study of drug development in India. Innovation: Management, Policy \& Practice, 12(2), 227-237. DOI: 10.5172/impp.12.2.227.

Messmann, G., \& Mulder, R. (2011). Innovative work behaviour in vocational colleges: Understanding how and why innovations are developed. Vocations and Learning, 4(1), 63-84. DOI: 10.1007/s12186-010-9049-y.

Mete, G. (2007). Orgutsel Ogrenme ve Yenilikci Is Davranisi /Organizational Learning and Innovative Work Behaviour/. Unpublished Master's Thesis, Gebze High Technology Institute. Kocaeli, Turkey.

Murray, H.A. (1938). Explorations in personality. New York: Oxford University Press.

Naranjo-Valencia, J.C., Jiménez-Jiménez, D., \& Sanz-Valle, R. (2011). Innovation or imitation? The role of organizational culture. Management Decision, 49(1), 55-72. DOI: 10.1108/00251741111094437.

Ojedokun, O. (2012). Role of perceived fair interpersonal treatment and organization-based self-esteem in innovative work behavior in a Nigerian bank. Psychological Thought, 5(2), 124-140. DOI: 10.5964/psyct.v5i2.33.

Oldham, G.R., \& Cummings, A. (1996). Employee creativity: Personal and contextual factors at work. Academy of Management Journal, 39(3), 607-634. DOI: 10.2307/256657.

Parjanen, S.M., Hennala, L., \& Laakso, S.K. (2012). Brokerage functions in a virtual idea generation platform: Possibilities for collective creativity? Innovation: Management, Policy \& Practice, 14(3), 363-374. DOI: 10.5172/impp.2012.14.3.363.

Petuskiene, E., \& Glinskiene, R. (2011). Entrepreneurship as the basic element for the successful employment of benchmarking and business innovation. Engineering Economics, 22(1), 69-77. DOI:10.5755/j01.ee.22.1.220.

Ramamoorthy, N., Flood, P.C., Slattery, T., \& Sardessai, R. (2005). Determinants of innovative work behaviour: Development and test of an integrated model. Creativity \& Innovation Management, 14(2), 142-150. DOI: 10.1111/j.1467-8691.2005.00334.x.

Reuvers, M., Van Engen, M.L., Vinkenburg, C., \& Wilson-Evered, E. (2008). Transformational leadership and innovative work behaviour: Exploring the relevance of gender differences. Creativity and Innovation Management, 17(3), 227-244. DOI: 10.1111/j.1467-8691.2008.00487.x.

Sanz-Valle, R., Naranjo-Valencia, J.C., Jiménez-Jiménez, D., \& Perez-Caballero, L. (2011). Linking organizational learning with technical innovation and organizational culture. Journal of Knowledge Management, 15(6), 997-1015. DOI: $10.1108 / 13673271111179334$. 
Sarı, I., Soyer, F., \& Yigiter, K. (2012). The relationship among sports coaches' perceived leadership behaviours, athletes' communication skills and satisfaction of the basic psychological needs. International Journal of Academic Research, 4(1), 112-119.

Schein, E.H. (1980). Organizational psychology ( $3^{\text {rd }}$ ed.). New Jersey: Prentice-Hall.

Scott, S.G., \& Bruce, R.A. (1994). Determinants of innovative behavior: A path model of individual innovation in the workplace. Academy of Management Journal, 37(3), 580-607. DOI: 10.2307/256701.

Shih, H., \& Susanto, E. (2011). Is innovative behavior really good for the firm? Innovative work behavior, conflict with coworkers and turnover intention: Moderating roles of perceived distributive fairness. International Journal of Conflict Management, 22(2), 111-130. DOI: 10.1108/10444061111126666.

Svagzdiene, B., Jasinskas, E., Fominiene, V.B., \& Mikalauskas, R. (2013). The Situation of learning and prospects for improvement in a tourism organization. Engineering Economics, 24(2), 126-134. DOI: 10.5755/j01.ee.24.2.1386.

Uzkurt, C., \& Sen, R. (2012). The effects of organizational culture and organizational innovation on marketing innovation: A research on carbonated beverage industry. Anadolu University Journal of Social Sciences, 12(3), 27-50.

Utterback, J.M. (1994). Mastering the dynamics of innovation. Boston, MA: Harvard Business School Press.

Walumbwa, F.O., Cropanzano, R., \& Hartnell, C.A. (2009). Organizational justice, voluntary learning behavior, and job performance: A test of the mediating effects of identification and leader-member exchange. Journal of Organizational Behavior, 30(8), 1103-1126. DOI: 10.1002/job.611.

West, M.A. (2002). Sparkling fountains or stagnant ponds: An integrative model of creativity and innovation implementation in work groups. Applied Psychology: International Review, 51(3), 355-387. DOI: 10.1111/14640597.00951 .

West, M.A., \& Anderson, N.R. (1996). Innovation in top management teams. Journal of Applied Psychology, 81(6), 680-693. DOI: 10.1037/0021-9010.81.6.680.

Xin, C., \& Shi, C. (2007). Correlative relationship of learning-oriented organizational innovation and technological innovation in Chinese high-tech manufacturing firms. In ICNC '07 Proceedings of the Third International Conference on Natural Computation, 24-27 August 2007 (pp. 543-549). Haikou, Hainan, China: IEEE Xplore. DOI: 10.1109/ICNC.2007.320.

Yang, J.T. (2007). Knowledge sharing: Investigating appropriate leadership roles and collaborative culture. Tourism Management, 28(2), 530-543. DOI: 10.1016/j.tourman.2006.08.006.

Yang, J.T., \& Wan, C.S. (2004). Advancing organizational effectiveness and knowledge management implementation. Tourism Management, 25(5), 593-601. DOI: 10.1016/j.tourman.2003.08.002.

Zieba, M., \& Zieba, K. (2014). Knowledge management critical success factors and the innovativeness of KIBS companies. Engineering Economics, 25(4), 458-465. DOI: 10.5755/j01.ee.25.4.6494.

Zukauskaite, E. (2012). Innovation in cultural industries: The role of university links. Innovation: Management, Policy \& Practice, 14(3), 404-415. DOI:10.5172/impp.2012.14.3.404.

\title{
AUTHOR'S ADDRESS:
}

\author{
Ersin Eskiler \\ Faculty of Sports Science \\ Sakarya University \\ 54187 Esentepe Campus \\ Sakarya, Turkey \\ E-mail: eeskiler@sakarya.edu.tr
}

Received: 25 December 2015; Accepted: 15 February 2016 